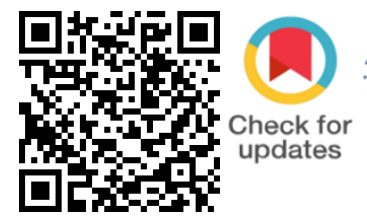

\title{
Impact of Banking Sector Reforms on Agriculture and Sources of Agricultural Credit
}

\author{
Saima Khan ${ }^{1} \mid$ Dr Shiv Kumar ${ }^{2}$ \\ ${ }^{1}$ Research Scholar, Noida International University \\ ${ }^{2}$ Head of School of Business Management, Noida International University
}

\section{To Cite this Article}

Saima Khan and Dr Shiv Kumar, "Impact of Banking Sector Reforms on Agriculture and Sources of Agricultural Credit", International Journal for Modern Trends in Science and Technology, Vol. 07, Issue 01, January 2021, pp.- 146-151.

Article Info

Received on 11-December-2020, Revised on 30-December-2020, Accepted on 06-January-2021, Published on 19-January-2021.

\section{ABSTRACT}

Agriculture industry plays an important role in the Indian economy and Banks can play an important role in bringing agricultural revolution, in removing indifference of wealth. Utilization of high technology and modern equipment in agriculture brings about production growth. Indian economy is emerging as one of the leading economies of the world which makes progress of agriculture sector very crucial. In an economy like India where agriculture is subsistence, Finance is considered as the basic ingredient for increase in agricultural productivity. Therefore, it becomes the main responsibility of the country is to provide strong support to this sector. Though impressive significant strides have been achieved in terms of spread network and outreach of institutions, the qualities of flow of financial resources to agriculture continue to be inadequate. The growth of agricultural credit in India depends mainly on Government intervention. Banking sector reforms directly affected the agricultural sector. This paper describes the effects of various banking sector reforms on agriculture and sources of agriculture credit.

Keywords: Banking Sector, GDP, Indian Agriculture Industry

\section{INTRODUCTION}

Agriculture industry plays a vital role in Indian's economy. It contributes about 17 percent to the total GDP and provides employment to over 60 percent of the population. Agriculture is the only means of earning for almost two-thirds of the employed class in India. Rural development occupies an important place in the overall economic development of the country. The Indian agricultural sector has been undergoing economic reforms since the early 1990s in the move to liberalize the economy to profit from Globalization. Gandhi ji said, "India lives in villages". He stressed the importance of rural character of the economy and regeneration of rural life. Since independence, it has been the constant effort of our policy makers to give adequate drive to rural development, as the sector is directly related to agriculture and is the main stay for the majority of the population of India but its success and failure depend to great level on the availability of adequate, timely and low cost credit from institutional sources, programs for the development of irrigation soil conservation, mechanization and increased use of inputs like fertilizers and pesticides which require substantial credit support.

Finance is considered as the basic ingredient for increase in agricultural productivity. As the income range of agricultural producers are not stable enough to realize the investments with their 
own budget, their working capital and investment needs are supported with loans. For this purpose, the government extends institutional credit to those who cannot afford to fully utilize the available technology. The contribution of the banking and financial sector to the current economic growth of the Indian economy is very crucial. Therefore, it becomes the main responsibility of the country is to provide strong support to this sector.

Banks and RBI can play an important role in bringing agricultural revolution, in removing indifference of wealth, and in the development of cottage industries. Utilization of high technology and modern equipment in agriculture brings about production growth. As the income range of agricultural producers are not stable enough to realize the investments with their own budget, their working capital and investment needs are supported with loans. For this purpose, the government extends institutional credit to those who cannot afford to fully utilize the available technology. The contribution of the banking and financial sector to the current economic growth of the Indian economy is very crucial. Though impressive significant strides have been achieved in terms of spread network and outreach of institutions, the qualities of flow of financial resources to agriculture continue to be inadequate. The growth of agricultural credit in India depends mainly on Government intervention.

\section{Objectives of the paper}

The present research has been carried out to achieve the following objectives:

1. To study the measures announced by the Government for increasing the flow of credit to agriculture

2. To study the broad policy measures declared by the Government of India for increasing the credit flow to agriculture

3. To observe the effect of banking sector reforms on agriculture and provide recommendations based on the findings of the research.

\section{Methodology of the Study}

The study has been conducted mainly on the basis of literature survey and secondary information. Various journals, research papers, Annual reports, and Newspaper articles have been surveyed in making this study.

\section{Agricultural Finance in India}

Agricultural development was the main concern of policy makers in the past fifty years and especially under various Five-year plans. Money available to the farmers through banks is in the form of short term credit for financial crop production programs and in the form of medium-term/ long-term credit for financing capital investments in agriculture and allied activities like land development including purchase of land, minor irrigation, farm mechanization, diary development, poultry animal husbandry, fisheries, plantation and horticulture. Loans are available for storage, processing and marketing of agricultural produce.

\section{Sources of Agricultural credit}

Two broad sources of agricultural credit in India are Non-Institutional Sources and Institutional Sources.

1. Non-institutional sources are money-lenders, traders, and credit from relatives, landlords and commission agents.

2. Institutional sources of Agricultural credit in India are Regional Rural banks, Co-operatives and Commercial banks.

These agencies have organized funds at their disposal and intend to meet short, medium and long-term needs of farmers. These institutions also follow a set of rules in granting loans. There are approximately 31 state cooperative banks, 55 regional rural banks in different states, 85 Commercial banks, 19 State Scheduled State Co-operative Bank.

\section{Measures taken by the Government for improving flow of credit}

\section{Agriculture credit package:}

Government of India decided in 2004 to double the flow of agriculture credit in three years with reference to base year 2003-04. The agriculture credit flow since 2003-04 has constantly exceeded the target. This is apparent from the fact that agriculture credit flow which was at INR. 86,981 crores in 2003-04 reached to INR. 468,291 crores in 2010-11. The agriculture credit target in 2011-12 was INR. 475,000 crore and ground level credit disbursement of INR. 511,029 crores were achieved (107\% of the target). In the year 2012-13 
as against the target of INR. 575,000 crores, achievement/credit disbursement was INR. 607,376 crores forming more than $105 \%$ of the annual target. Agriculture credit of INR. $7,11,621.47$ crores $(102 \%$ of the target) was distributed exceeding the target of INR. 700,000 crores fixed for the year 2013-14. The target for the year 2014-15 was fixed at INR. 800,000 crore and accomplishment were INR. 845,328.23 crores. The target for 2015-16 is INR. 8,50,000 crore and achievement are INR. 8,77,527 crores. The aim of year 2016-17 has been set at INR. 9,00,000 crores and a sum of INR. 755,995.17 crores have been already released as agriculture credit during April-September, 2016.

Interest grant to farmers: Interest grant of $2 \%$ per annum to Public Sector Banks, Private Sector Scheduled Commercial Banks (in respect of loans given by the rural and semi urban branches), Cooperative Banks and Regional Rural Banks on their own funds used for short term crop loans up to Rs.3.00 lakh per farmer provided the lending institutions make available short-term credit at the ground level at $7 \%$ per annum to farmers. $2 \%$ interest financial support will be intended on the crop loan amount from the date of its disbursement/ drawl up to the date of actual repayment of the crop loan by the farmer or up to the due date of the loan fixed by the banks, whichever is earlier, subject to a maximum period of one year.

Kisan Credit Card Scheme: A Kisan Credit Scheme was launched in 1998-99 to make sure that all eligible farmers are provided with easy access and timely funds for their operations related to agriculture. Farmers which are to be covered in this scheme were Marginal farmers, share croppers, oral lessee and tenant farmers. The main aim of the Scheme is; to fulfill the requirement of credit for cultivation of crops, expenses required for post-harvest needs, produce marketing loan, funds required for farmers for their household consumption, capital required for maintenance of farm assets and activities allied to agriculture, like dairy animals, inland fishery etc. Credit required for investment for agriculture and allied activities like pump sets, sprayers, dairy animals etc. The State Governments have also been counsel to launch an intensive and broad branch/village level awareness campaign to provide Kisan Credit Card to all the eligible and willing farmers in a time bound manner KCCs have now been converted for the convenience of the farmers into Smart Card cum Debit Cards to make its operation easy through ATMs. The cumulative number of live KCCs issued by Commercial Banks, Cooperative Banks \& Regional Rural Banks as on 31 March, 2016 was INR. 752.72 lakh with outstanding loan amount of INR. 530034.58 crore.

\section{Agriculture cover (insurance):}

Effects of unpredictable climate in India such as unreliable rainfall distribution over time and space and occurrence and severity of droughts, floods and cyclones have also increased along with rising temperatures, all of this have resulted in uncertainty and risk resulting in losses in agricultural production and of livestock population in India. In order to provide solution to the farmers from any event of failure of any of crop as a result of natural calamities, pests and diseases, a comprehensive insurance solution was provided which was called The National Agricultural Insurance Scheme (NAIS) for crops and was implemented from rabi 1999-2000 season. Regardless of the size of farm holding, this scheme was made available to all the farmers (both loaner and non-loaner).

This scheme operates on the basis of "Area Approach," in which a particular area, viz., tehsil or block or nyaya panchayat or gram panchayat etc is considered as unit of insurance instead of individual arm holdings. Coverage of those crops was covered in this scheme of which past yield data are available for an adequate number of years such as the food crops (cereals, millets and pulses), oilseeds and other annual commercial/horticultural. At present, subsidy in premium is available to small and marginal farmers are 10 per cent, which is to be shared equally by the Centre and State Governments. The scheme at present is being implemented by 24 states and 2 Union Territories. Since the start of the scheme and until rabi 2007-08 about 1,155 lakh farmers have been covered. 184 million hectares is the coverage area and the sum insured are INR.1, 21,606 crores. Claims to the tune of about INR. 11,607 crores have been found against the premium income of about INR. 3,626 crores benefiting nearly 302 lakh farmers.

\section{Scheme for distraught Farmers:}

The main objective of this package is to provide sustainable and viable farming and livelihood support system to distraught farmers through helping farmers in their debt, better access to supply of institutional credit, a crop-centric approach to agriculture, better irrigation facilities 
and watershed management, better extension of farming support services, and subsidiary income opportunities through horticulture, livestock, dairying, fisheries etc.

\section{Easy Access:}

Banks have been issued guidelines from RBI to waive margin/security requirements for agricultural loans up to Rs50,000 and agri-business and agro-clinics up to INR.5 lakhs. With the help of an agency, RBI also conducted a survey to make an assessment of customer satisfaction on credit delivery in rural areas by banks.

Instructions for aid to be provided in case of Natural Calamities:

Specific course of action has been defined by RBI for providing relief to farmers in area affected by natural calamities. These guidelines were issued by RBI to provide farmers financial assistance affected by natural calamities and also help banks to take uniform and intensive action. It was instructed to Reschedule/Restructure of any outstanding loan of the farmers in Districts declared as calamity. Rescheduled loan shall be repayable over a period of 5 years, at current interest rates, including an initial moratorium of two years.

\section{National Agricultural Insurance Scheme (NAIS)}

This scheme was launched mainly to help protect farmer's interest against crop losses suffered on account of natural calamities, such as drought, flood, pests and diseases. The program was implemented by the Agricultural Insurance Company of India Ltd (AICL). It was made available to all farmers both loaner and non-loaner irrespective of their size of holding. It envisages coverage of all food crops (cereals, millets and pulses), oil seeds, and annual commercial/horticultural crops, in respect of which past data is available for an adequate number of years

Rural Infrastructural Development Fund (RIDF) NABARD is a main organization to look after the credit requirements of the rural sector. And also plays a very important role in the development of rural areas, by assisting the agricultural sector through Co-operative banks, Regional Rural Banks and commercial banks. The Rural Infrastructural Development Fund which was set up in 1995-1996 is also administered by NABARD. The main purpose of this fund is to provide loans to state Governments and state-owned corporations for completing the on-going projects relating to medium and minor irrigation, soil conservation, watershed management and other forms of rural infrastructure. All scheduled commercial banks other than foreign banks operating in India which have not reached the agricultural lending sub-target of $18 \%$ of net bank credit would be required to contribute to the RIDF.

\section{Micro-Credit:}

Through the medium of self-help groups (SHGS), NABARD plays an important role in microcredit. NABARD has played a vital role in the development of rural areas by assisting the agricultural sector through Cooperative banks, Regional Rural Banks and Commercial banks. A major part of short term credit support of NABARD's is distributed for financing seasonal Agricultural Operations (SAO). NABARD provides refinance assistance under the Integrated Rural Development programmes (IRDP) for schemes like minor irrigation dairy development sheep/goat development, land development, poultry, fisheries etc. NABARD has set up a Research and Development Fund for granting assistance to SCBs, RRBs, and various other institutions. The three main functions of NABARD are refinancing, institutional development and inspection of District and State Co-operative Banks and Regional Rural Banks.

Important Policy Measures in Agricultural Sector during the Various Plans

\section{Land Reforms}

Land reform measures to abolish intermediaries and to transfer land to the actual tillers of the soil. Abolition of intermediaries and Tenancy reforms are the various measures taken in this regard.

\section{Technological Measures}

To sustain and extend the agricultural development programmes to larger areas of the country, steps were taken to increase the production of high yielding varieties of seeds, fertilizers.

\section{Institutional Credit:}

An important measure initiated was to make available the institutional credit to farmers, especially through co-operatives and commercial 
banks. As a result of these measures the importance of money lenders declined to a great extent.

\section{Subsidies:}

The Government of India has provided various subsidies to farmers on agricultural inputs like irrigation fertilizers, electricity and credit. 4.2.5 Public Distribution System One of the important measures taken by the government of India was to introduce Public Distribution System (PDS). The basic idea of introducing this was to provide food grains and other essential goods to consumers at cheap and subsidised rates. Rural Employment Programs Government of India has introduced several rural employment programmers over the various Five Year Plans Some of them are- Small Farmers Development Agency (SFDA), Marginal Farmers and Agricultural Labours Development Agency (MFAL), Integrated Rural Development Program(IRDP), Jawahar Rojgar Yojana(JRY)

\section{Other measures}

1. Provision and extension of irrigation facilities through major/medium projects and power for minor irrigation through the rural electrification programmes.

2. Improving the system of agricultural marketing through the establishment of regulated markets and introducing other measures such as standardization of weights, grading etc.

3. Provision and expansion of storage and warehousing facilities so that the government can build up buffer stocks to cope with the food problems in case of emergency.

Indian Banking sector has undergone changes and reforms during economic reforms. Though it was a part of overall economic reforms, it has changed the very functioning of Indian banks. The banking sector is an important subsector of financial sector which plays the role of financial intermediary. This reform has not only left everlasting footprints on agriculture but have also influenced the productivity and efficiency of many Indian Banks. Major objective of banking sector reforms has been to enhance efficiency and productivity through increased competition. Economic reforms in banking sector affected the agriculture sector.

\section{Major economic reforms in Banking sector in India and its impact on agricultural credit:}

Impact of Banking Sector Reforms on Agriculture

\section{Decontrol of Interest Rate}

During economic reforms period, government regulatory controls on interest rates of commercial banks was removed Interest on bank loan above INR. 2 lakhs are fully decontrolled. Purpose was to give more freedom to commercial banks in interest rate regime. It adversely affects agricultural sector credit.

CRR and SLR was reduced: Cash reserve ratio (CRR) is a specific amount of the total bank deposits which has to be kept with RBI which means banks do not have access to that much amount for any economic or commercial activity and Statutory liquidity ratio(SLR) is the amount of money that is invested in certain specified securities mainly central government and state government securities. Both are steadily reduced during the economic reforms period in India. It is reduced from the earlier high level of $15 \%$ to 4\%level. Now CRR is $4 \%$.SLR is also reduced from early $38.5 \%$ to current minimum of $22 \%$ level. This has left more loan able funds with commercial banks, solving the liquidity problem. But the commercial banks not utilise the excess fund for providing agricultural loans. Commercial banks invest in diversified activities.

\section{Risk Management:}

During the economic reforms period, the Indian banking sector was well diversified and many banks started new services and launched new schemes. Some of them have established subsidiaries in merchant banking, mutual fund, insurance etc which has led to diversified source of income of them. All commercial banks especially new generation banks engaged in diversified activities to improve the profitability. Hence less importance is given to agricultural credit.

\section{Emergence of New Generation Banks:}

Many new generation banks have successfully emerged in the financial horizon during reforms period. As per the Guidelines of RBI, all commercial banks which have not reached the agricultural lending sub-target of $18 \%$ of net bank credit would be required to contribute to the RIDF.

Banks Operational Independence: 
During the reforms period commercial banks employed the operational freedom. Freedom in opening new branches, they get liberal lending norms etc. As a result, banks give loans to allied activities of agriculture such as loan to fertilizers company, agency etc. It is not available to the original farmers for their agricultural purposes.

\section{Conclusion:}

Increase agricultural production in India depends greatly on important role played by agriculture credit. The target of agricultural credit flow was fixed at INR. 700,000crore during 2013-14 and the achievement INR.7,23,225crore, represents 103\% of target. The banks (including RRBs and Co-operatives) have issued $869928 \mathrm{KCCs}$ (Kisan Credit Cards) during 2013-14 with credit limit of INR. 10461 crore. A review of performance of agricultural credit in India reveals that though the overall flow of institutional credit has increased over the years, there are several gaps in the system like inadequate provision of credit to small and marginal farmers, limited deposit mobilization and heavy dependence on borrowed funds.

Efforts are required to address and rectify these issues. Banking sector reforms like fixing prudential norms, reduced SLR, CRR, banking diversification all affect the Indian agricultural sector. CRR is reduced to $4 \%$, it provides more loan able funds to the banks. The choice of a credit outlet and quantum of institutional credit availed by farming households have been found to be affected by a number of socio-demographic factors. The effect of education has indicated the need for capacity building of borrowing farmers. Imparting training to borrowers regarding procedural formalities of financial institutions could be helpful in increasing their access to institutional credit. For building the necessary institutional and marketing infrastructure agricultural financial institutions are needed to cater to the requirements of finance. Banks and Government should evaluate their pre-conceived notions about commercial opportunities in serving the rural and agricultural sector. Co-operative banks and RRBs should enlarge the scope of the KCC scheme to cover term loans for agriculture and allied activities.

\section{References}

[1] Dr. Anupama Rajput. AGRICULTURE CREDIT IN INDIA. Lesson5, Study, Material-2, Economics, School of Open learning, University of Delhi.

[2] Dr. Subbarao (2012). Agricultural Credit Accomplishments and challenges. Indian Bankers,Vol-7, No.8.

[3] Kewal, K., \& Atul, G. (2012). Financing of agriculture by commercial banks-problems faced by farmers:(an empirical study). Commerce and Management, 1(5), 79-84.

[4] Tyagi, V. (2012). India's agriculture: challenges for growth \& development in present scenario. International Journal of Physical and Social Sciences, 2(5), 116-128.

[5] Pande and Priyakumar (2013). Meeting Future credit needs of Agriculture. The Indian Banker,Vol.1, No.5.

[6] Gandhimathi, S. (2012). Distribution of agricultural credit in the pre and post reform period. International Journal of Managment, IT and Engineering, 2(9), 243-253.

[7] Gowar Bashir Ahanger, Ashaq Hussain Gaine and MohdUmmer Jan Padder, (2013), "A study on institutional Credit to agricultural sector in India”, Inernational journal of current Research and Academic review.

[8] Annual Report, Ministry of Agriculture (2012) Gyani. Laws and practices relating to Banking" Mumbai: Jeevandeep Prakashan.

[9] Sandhu, H. K. (2012). Doubling of agricultural credit its efect on farmers and current agriculture senerio. International Journal of Social Science and Interdisciplinary Research, 1(7), 126-133.

[10] NABARD, Annual Report 2008-09 to 2013-14. Pratap Bapuso Lad (2013), Agriculture Finance: An overview. Research direction, vol-1, Issue 1.

[11] Policy Initiatives taken by the Government for increasing flow of credit and removal of indebtedness from non-institutional sources of lending. Available at: http://agricoop.nic.in/sites/default/files/Agriculture-Cre dit-Overview.pdf.

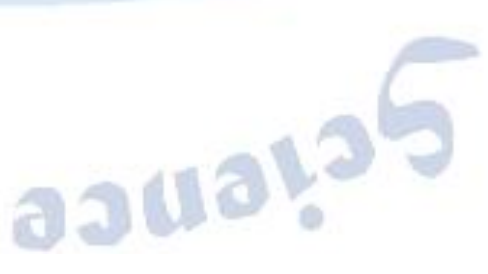

